\title{
Radiation Induced Br-Transfer from Ethylbromide to Triethylsilane
}

\author{
Yu. M. Lugovoi* and N. Getoff** \\ Institute of Theoretical Chemistry and Radiation Chemistry, University of Vienna and \\ Ludwig Boltzmann Institute of Radiation Chemistry, both Währingerstraße 38, \\ A-1090 Wien, Austria \\ Z. Naturforsch. 44b, 1373-1376 (1989); received May 30, 1989 \\ Radiation Induced Br-Transfer, Ethylbromide, Triethylsilane \\ The radiolysis of deoxygenated triethylsilane $\left(\mathrm{Et}_{3} \mathrm{SiH}\right)$ was studied in the presence of various \\ concentrations of ethylbromide $(\mathrm{EtBr})$ as a function of the radiation dose. Chain reactions are \\ leading to rather high yields of Br-containing final products, e.g. using $0.93 \mathrm{~mol} / \mathrm{dm}^{3} \mathrm{EtBr}$ we \\ obtained: $\mathrm{G}_{\mathrm{i}}\left(\mathrm{Et}_{3} \mathrm{SiBr}\right)=138, \mathrm{G}_{\mathrm{i}}(\mathrm{HBr})=40, \mathrm{G}_{\mathrm{i}}\left(\mathrm{Br}_{2}\right)=15$ and $\mathrm{G}_{\mathrm{i}}\left(\mathrm{Et}_{3} \mathrm{Si}-\mathrm{SiEt}_{3}\right)=6$, in addition to \\ small amounts of unidentified oligomers. Based on the knowledge from previous steady-state and \\ pulse radiolysis studies of $\mathrm{Et}_{3} \mathrm{SiH}$, a probable reaction mechanism is postulated to allow explana- \\ tion of the present results.
}

\section{Introduction}

The chemistry of silanes, especially of organopolysilanes, where the backbone is a linear chain of silicon atoms, has recently attracted much interest. In order to better understand the reaction mechanism, halogenated silanes were used. In an earlier work by Ihlein et al. [1] several halogenated silanes in 2-methyltetrahydrofuran have been used for studies on the readiation induced formation of specific radicals at $-196{ }^{\circ} \mathrm{C}$ under steady-state conditions. The observed absorption spectra were attributed to the corresponding radical anions and neutral species. The reactivity towards the free electrons $\left(\mathrm{e}_{\mathrm{aq}}^{-}\right)$is found to decrease with increasing number of methyl groups and to rise with growth of phenyl groups of the silanes. Lugovoi et al. [2] studied the radiation induced oxidation of ethyldichlorosilane, which results in the formation of chlorine-containing disiloxane. In addition to this a radical-chain process has been observed in the co-telomerization of ethylene and 1-hexene with ethyldichlorosilane [3, 4]. Pure triethylsilane $\left(\mathrm{Et}_{3} \mathrm{SiH}\right)$ has been a subject of rather extensive steady-state and pulse radiolysis investigations [5]. As a consequence of the radiolysis, 19 final products in deoxygenated as well as in $\mathrm{N}_{2} \mathrm{O}$ saturated $\mathrm{Et}_{3} \mathrm{SiH}$ have been found and their initial G-values

\footnotetext{
* On leave from Department of Chemical Technology, Mendeleev University, Miusskaja Pl. 9, Moscow, USSR.

** Author to whom correspondence should be addressed.

Verlag der Zeitschrift für Naturforschung, D-7400 Tübingen $0932-0776 / 89 / 1100-1373 / \$ 01.00 / 0$
}

$\left(G_{i}\right)^{+}$determined. The total transient absorption with $\lambda_{\max }=260 \mathrm{~nm}$ disappears with an apparent rate constant of $\mathrm{k}=1.85 \cdot 10^{9} \mathrm{M}^{-1} \mathrm{~s}^{-1}$.

Finally, the observation of polysilane radical anions [6] and the effect of side chains studies by pulse radiolysis have been reported recently [7].

The aim of the present studies was to investigate the possibility of radiation induced transfer of a halogen atom from a halogenated organic compound, e.g. ethylbromide $(\mathrm{EtBr})$, to triethylsilane $\left(\mathrm{Et}_{3} \mathrm{SiH}\right)$ in airfree media.

\section{Experimental}

The chemicals used were of p.A. purity (Merck, Darmstadt). Triethylsilane was further purified as previously described [5]. Prior to irradiation high purity argon was bubbled through the solutions in the irradiation vessels for about $1 \mathrm{~h}$ in order to remove oxygen. Solutions of various concentrations of $\mathrm{EtBr}$ in $\mathrm{Et}_{3} \mathrm{SiH}$ were irradiated as a function of radiation dose.

A "Gammacell 220" (Atomic Energy of Canada Ltd.) was used as ${ }^{60} \mathrm{Co}-\gamma$-source. The dosimetry was performed by means of ferrous-copper dosimeter [8] under the same experimental conditions (dose rate: $41 \mathrm{~Gy} / \mathrm{min})^{++}$.

The analysis of the $\mathrm{Et}_{3} \mathrm{SiH} / \mathrm{EtBr}$ system irradiated at various doses was performed by GC ("Carlo Erba

\footnotetext{
${ }^{+} \mathrm{G}_{\mathrm{i}}=$ initial $\mathrm{G}$-value represents the yield (number of molecules produced per $100 \mathrm{eV}$ absorbed energy) of final products calculated from the tangent thrnigh the coordinate origin to the yield-dose curve.

$+1 \mathrm{~Gy}=100 \mathrm{rad}=6.24 \cdot 10^{15} \mathrm{eV} / \mathrm{g}$ sample.
} 
Fractovap 2300"; porapax Q Se 30 10\% CPS 80/100; temperature upto $250^{\circ} \mathrm{C}$ ). The product yields were determined by comparison with the concentration of standard samples. Some analyses were carried out by combined GC/MS (Varian-Aerograph and Varian MAT $\mathrm{CH} 7 \mathrm{~A}$ with data system) ${ }^{+++}$.

\section{Results}

Various concentrations of $\operatorname{EtBr}(0.23,0.50,0.93$, $1.30,1.75$ and $2.69 \mathrm{~mol} / \mathrm{dm}^{3}$ ) in $\mathrm{Et}_{3} \mathrm{SiH}$ were used. As a consequence of the radiolysis of the $\mathrm{Et}_{3} \mathrm{SiH} /$ EtBr-system two Br-containing products $(\mathrm{HBr}$ and $\left.\mathrm{Et}_{3} \mathrm{SiBr}\right)$ in addition to hexaethyldisilane $\left(\mathrm{Et}_{3} \mathrm{Si}-\mathrm{SiEt}_{3}\right), \mathrm{Br}_{2}$ and a mixture of unidentified oligomers were obtained. Fig. 1 illustrates the course of the EtBr decomposition $\left(G_{i}=58\right)$ and the formation of $\mathrm{Et}_{3} \mathrm{SiBr}\left(\mathrm{G}_{\mathrm{i}}=32.8\right)$ and $\mathrm{HBr}\left(\mathrm{G}_{\mathrm{i}}=19.3\right)$ as a function of dose.

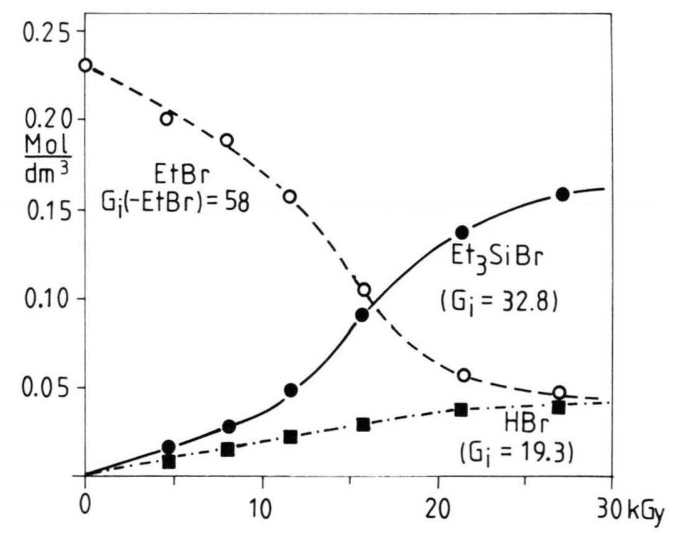

Fig. 1. Radiolysis of $0.23 \mathrm{~mol} / \mathrm{dm}^{3}$ ethylbromide (EtBr) in deoxygenated triethylsilane $\left(\mathrm{Et}_{3} \mathrm{SiH}\right)$ with formation of $\mathrm{Et}_{3} \mathrm{SiBr}$ and $\mathrm{HBr}$ as a function of dose.

It is to be noted that the yield of $\mathrm{Et}_{3} \mathrm{SiBr}$ is nearly a mirror-image of the EtBr decrease. The rather high product yields indicate the occurrence of chain reactions. The shape of the curves, however, strongly changes with increasing $\mathrm{EtBr}$ concentration. Using $0.93 \mathrm{~mol} / \mathrm{dm}^{3} \mathrm{EtBr}$, the yield of $\mathrm{Et}_{3} \mathrm{SiBr}$ is strongly increased $\left(G_{i}=138\right)$ and is proportional to the absorbed radiation dose. Also the yields of $\operatorname{HBr}\left(G_{i}=\right.$ $40)$ and the decomposition of $\operatorname{EtBr}\left(G_{i}=205\right)$ are increased (Fig. 2).

${ }^{+++}$The valuable help by Doz. Dr. Alexej Nikiforov is greatly appreciated.

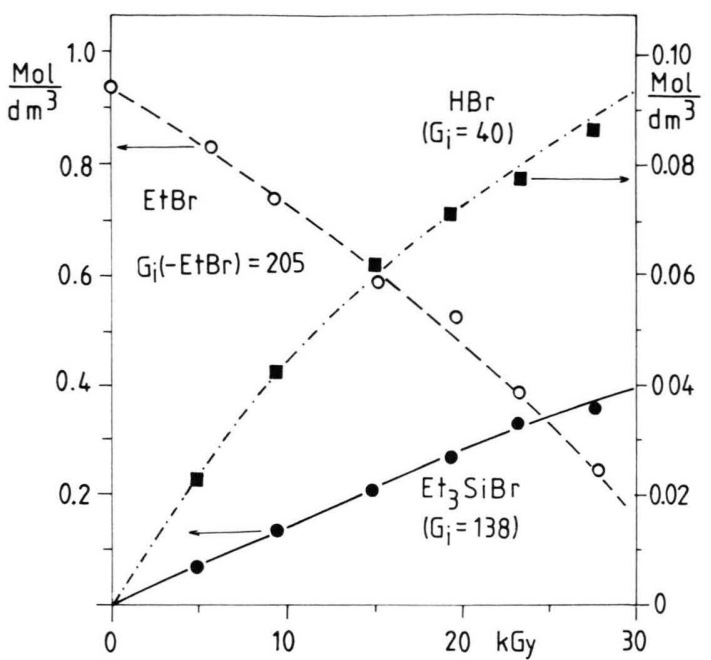

Fig. 2. Decomposition of $\mathrm{EtBr}$ as well as formation of $\mathrm{Et}_{3} \mathrm{SiBr}$ and $\mathrm{HBr}$ from $0.93 \mathrm{~mol} / \mathrm{dm}^{3} \mathrm{EtBr}$ in air-free $\mathrm{Et}_{3} \mathrm{SiH}$ as a function of dose.

A further increase of the $\mathrm{EtBr}$ content in the deoxygenated $\mathrm{Et}_{3} \mathrm{SiH}$ resulted in a decrease of the product yields as shown in Fig. 3. The radiation induced decomposition of $\mathrm{EtBr}$ is also reduced. Under these conditions a recombination of the radicals very likely takes place leading to reformation of the starting compounds. This effect became even more pronounced with further increase of the $\mathrm{EtBr}$-concentration up to $2.68 \mathrm{~mol} / \mathrm{dm}^{3}$, where $\mathrm{G}_{\mathrm{i}}(\mathrm{HBr})=10$ and $\mathrm{G}_{\mathrm{i}}\left(\mathrm{Et}_{3} \mathrm{SiBr}\right)=30$.

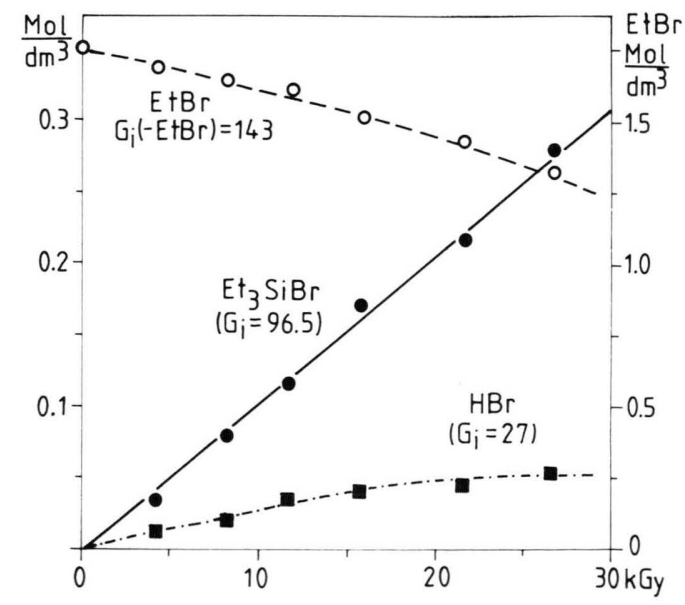

Fig. 3. Product formation $\left(\mathrm{Et}_{3} \mathrm{SiBr}\right.$ and $\mathrm{HBr}$ ) and $\mathrm{EtBr}$ consumption by radiolysis of $1.75 \mathrm{~mol} / \mathrm{dm}^{3} \mathrm{EtBr}$ in air-free $\mathrm{Et}_{3} \mathrm{SiH}$ as a function of dose. 
For a better survey the $\mathrm{G}_{\mathrm{i}}$-values obtained from all experimental series are compiled in Table I. Obviously the highest $\mathrm{G}_{\mathrm{i}}$-values of the products are observed by using $1.3 \mathrm{~mol} / \mathrm{dm}^{3} \mathrm{EtBr}$ in $\mathrm{Et}_{3} \mathrm{SiH}$.

Table I. Initial $\mathrm{G}$-values $\left(\mathrm{G}_{\mathrm{i}}\right)$ of $\mathrm{EtBr}$ consumption and products formed by radiolysis of $\mathrm{Et}_{3} \mathrm{SiH}$ in the presence of various $\mathrm{EtBr}$ concentrations.

\begin{tabular}{lccccl}
\hline $\begin{array}{l}\mathrm{EtBr} \\
\left(\mathrm{mol} / \mathrm{dm}^{3}\right)\end{array}$ & $\mathrm{G}_{\mathrm{i}}$-values \\
$\begin{array}{l}\text { in } \\
\text { Consumpt. }\end{array}$ & & & & \\
$\mathrm{Et}_{3} \mathrm{SiH}$ & $\begin{array}{l}\text { of EtBr } \\
\text { of }\end{array}$ & $\mathrm{Et}_{3} \mathrm{SiBr}$ & $\mathrm{HBr}$ & $\mathrm{Br}_{2}$ & $\mathrm{Et}_{3} \mathrm{Si}-\mathrm{SiEt}_{3}$ \\
\hline 0.23 & 58 & 32.8 & 19.3 & 5 & n.d. \\
0.50 & 90 & 50 & 20 & 8 & 8 \\
0.93 & 205 & 138 & 40 & 15 & 6 \\
1.30 & 250 & 140 & 44 & n.d. & n.d. \\
1.75 & 143 & 96.5 & 27 & 25 & n.d. \\
2.68 & 85 & 34 & 12 & 20 & 5 \\
\hline
\end{tabular}

\section{Discussion}

The primary radiolysis products resulting from $\mathrm{Et}_{3} \mathrm{SiH}$ and their $\mathrm{G}_{\mathrm{i}}$-values (given in brackets) are presented by the brutto reaction (1) [5]:

\begin{tabular}{|c|c|c|}
\hline \multicolumn{3}{|c|}{$\mathrm{Et}_{3} \mathrm{SiH} \longrightarrow m \mathrm{H}, \mathrm{e}_{\mathrm{s}}^{-},\left(\mathrm{Et}_{3} \mathrm{SiH}^{+} \cdot \mathrm{e}^{-}\right), \mathrm{H}_{2}}$, \\
\hline $\begin{array}{l}\dot{\mathrm{C}} \mathrm{H}_{3}, \\
(0.075)\end{array}$ & $\begin{array}{l}\dot{\mathrm{C}}_{2} \mathrm{H}_{5}, \\
(3.60)\end{array}$ & $\begin{array}{l}\mathrm{Et}_{3} \dot{\mathrm{Si}} \\
(3.75)\end{array}$ \\
\hline $\begin{array}{l}\mathrm{Et}_{2} \dot{\mathrm{SiH}}, \\
(3.60)\end{array}$ & \multicolumn{2}{|c|}{$\begin{array}{l}\mathrm{CH}_{3} \dot{\mathrm{C}} \mathrm{HSi}(\mathrm{H}) \mathrm{Et}_{2}, \\
(0.27)\end{array}$} \\
\hline $\begin{array}{l}\dot{\mathrm{C}} \mathrm{H}_{2} \mathrm{CH} \\
(0.17)\end{array}$ & (H) $\mathrm{Et}$ & $\begin{array}{l}\dot{\mathrm{C}} \mathrm{H}_{2} \mathrm{Si}(\mathrm{H}) \mathrm{Et}_{2} \\
(0.075)\end{array}$ \\
\hline
\end{tabular}

The most important species in the present case are: $\mathrm{e}_{\mathrm{s}}^{-},\left(\mathrm{Et}_{3} \mathrm{SiH}^{+} . \mathrm{e}^{-}\right), \mathrm{H}, \mathrm{Et}_{3} \dot{\mathrm{S}} \mathrm{i}, \dot{\mathrm{E}} \mathrm{t}, \mathrm{Et}_{2} \dot{\mathrm{S}} \mathrm{iH}$. At lower $\mathrm{EtBr}$ concentrations in $\mathrm{Et}_{3} \mathrm{SiH}$ the following reaction steps are very likely:

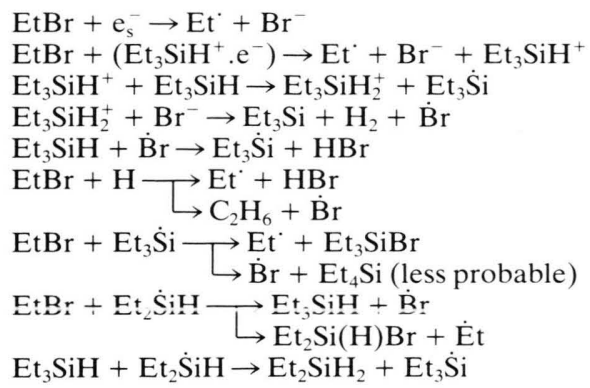

According to reactions (2), (3), (7a), (8a) and (9b) Et radicals are formed, which can initiate a chain reaction, namely:

$$
\mathrm{Et}_{3} \mathrm{SiH}+\mathrm{Et}^{\cdot} \rightarrow \mathrm{Et}_{3} \dot{\mathrm{Si}}+\mathrm{C}_{2} \mathrm{H}_{6}
$$

The $\mathrm{Et}_{3} \dot{\mathrm{S}} \mathrm{i}$ radicals thus produced, together with those formed by reactions (4) to (6) and (10) are consumed by reaction (8a) resulting in the main product, $\mathrm{Et}_{3} \mathrm{SiBr}$ and again $\mathrm{Et}{ }^{\prime}$ radicals. A second chain process is started by the formation of $\dot{\mathrm{Br}}$ species (see reactions (5) and (9a)). The Br transients are consumed by reaction (6), whereby $\mathrm{HBr}$ and $\mathrm{Et}_{3} \dot{\mathrm{Si}}_{\mathrm{i}}$ transients are resulting. Reaction (7a) also contributes to the formation of $\mathrm{HBr}$. Probably to a small extent the radical cations $\mathrm{Et}_{3} \mathrm{SiH}^{+}$can react with $\mathrm{Br}^{-}$ by an electron transfer in competition to reaction (4).

$$
\mathrm{Et}_{3} \mathrm{SiH}^{+}+\mathrm{Br}^{-} \rightarrow \dot{\mathrm{Br}}+\mathrm{Et}_{3} \mathrm{SiH}^{*} \rightarrow \mathrm{Et}_{3} \dot{\mathrm{S}} \mathrm{i}+\mathrm{H}
$$

In this case three reactive species can be formed $\left(\dot{\mathrm{Br}}, \dot{\mathrm{H}}\right.$ and $\left.\mathrm{Et}_{3} \dot{\mathrm{Si}}\right)$, which are consumed as shown above.

With increasing $\mathrm{EtBr}$ concentration a direct radiolysis starts to play a role, namely:

$$
\mathrm{EtBr} \longrightarrow \mathrm{EtBr}^{*} \rightarrow \mathrm{Et}^{+}+\mathrm{Br}^{-}+\mathrm{Br}^{-}
$$

$\mathrm{Et}^{*}$ and $\mathrm{Br}^{\cdot}$ transients are strongly contributing to an increase of the main product yields. The $\mathrm{Et}^{+}$ transients can be scavenged in the bulk of the solution, e.g.:

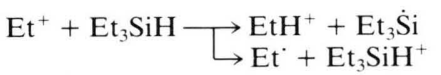

$$
\begin{aligned}
& \mathrm{EtH}^{+}+\mathrm{e}_{\mathrm{s}}^{-} \rightarrow \mathrm{EtH}^{*} \rightarrow \mathrm{Et}^{*}+\mathrm{H}
\end{aligned}
$$

The possible fate of $\mathrm{Br}^{-}$is shown by reactions (5) and (12). Clearly, these processes explain the strong rise of the product yields presented in Fig. 2 compared to those in Fig. 1.

With further increase of the EtBr concentration, however, a decrease of the product yields is observed (Fig. 3 and Table I). This effect can be referred to back reactions initiated by the higher yield of the species resulting from reactions (13) to (15), which can lead to a reformation of the starting compounds, e.g.:

$$
\begin{aligned}
& \mathrm{Et}+\mathrm{Br}^{\cdot} \rightarrow \mathrm{HBr} \\
& \mathrm{Et}_{3} \dot{\mathrm{Si}}+\mathrm{H} \rightarrow \mathrm{EtSiH}^{\circ}
\end{aligned}
$$

Finally, it might be mentioned, that besides the formation of various products [5] the $\mathrm{Et}_{3} \dot{\mathrm{S}} \mathrm{i}$ radicals can also combine to give hexaethyldisilane as shown in Table I (see reaction (18)). By increasing the concentration of $\mathrm{EtBr}$ in $\mathrm{Et}_{3} \mathrm{SiH}$, the probability of $\mathrm{Br}$ 
atom combination to $\mathrm{Br}_{2}$ is rised (Table II, reaction (19)).

$$
\begin{aligned}
& 2 \mathrm{Et}_{3} \mathrm{Si} \rightarrow \mathrm{Et}_{3} \mathrm{Si}-\mathrm{SiEt}_{3} \\
& 2 \mathrm{Br} \rightarrow \mathrm{Br}_{2}
\end{aligned}
$$

\section{Conclusion}

The radiation induced formation of $\mathrm{Et}_{3} \mathrm{SiBr}$ and $\mathrm{HBr}$ from $\mathrm{Et}_{3} \mathrm{SiH}$ using various concentrations of $\mathrm{EtBr}$ in absence of air was investigated as a function of radiation dose. The highest product yields, $\mathrm{G}_{\mathrm{i}}\left(\mathrm{Et}_{3} \mathrm{SiBr}\right)=140$ and $\mathrm{G}_{\mathrm{i}}(\mathrm{HBr})=44$, were achieved by using $1.30 \mathrm{~mol} / \mathrm{dm}^{3} \mathrm{EtBr}$. Taking into considera- tion the knowledge obtained by previous steady-state and pulse radiolysis studies of $\mathrm{Et}_{3} \mathrm{SiH}$ [5], a probable reaction mechanism involving chain reaction steps is presented. The method can be used for production of $\mathrm{Et}_{3} \mathrm{SiBr}$.

One of us (N.G.) greatly appreciates the financial support by the Jubilee Fonds of the Austrian National Bank, which made possible the computerization of various apparatus. Yu. M. L. thanks the Federal Ministry for Science and Research in Austria for the grant of a fellowship.
[1] W. Ihlein, J. Wendenburg, and A. Henglein, Z. Naturforsch. 23b, 1403 (1968).

[2] Yu. M. Lugovoi, A. G. Shostenko, N. P. Tarasova, C. Filliatre, and G. Bourgeois, React. Kinet. Catal. Lett. 24, 131 (1984).

[3] Yu. M. Lugovoi, A. G. Shostenko, P. A. Zagorets, and V. P. Krapchatov, React. Kinet. Catal. Lett. 24, 329 (1984).

[4] Yu. M. Lugovoi, A. G. Shostenko, P. A. Zagorets, and V. P. Krapchatov, React. Kinet. Catal. Lett. 24, 335 (1984).
[5] N. Getoff, A. Ritter, and F. Schwörer, Radiat. Phys. Chem. 28, 343 (1986).

[6] H. Ban, K. Sukegawa, and S. Tagawa, Macromolecules 20, 1775 (1987).

[7] H. Ban, K. Sukegawa, and S. Tagawa, Macromolecules 21, 45 (1988)

[8] N. Getoff, K. Kaindl, and E. H. Graul (eds): Strahlenchemie, pp. 226-249, Hüthig Verlag, Heidelberg (1967). 